Article

\title{
Pigs and Pollards: Medieval Insights for UK Wood Pasture Restoration
}

\section{Dolly Jørgensen}

Umeå University, Department of Ecology \& Environmental Science, 90187 Umeå, Sweden; E-Mail: dolly@jorgensenweb.net; Tel.: +46-90-786-65-53; Fax: +46-90-786-67-05

Received: 13 December 2012; in revised form: 14 January 2013 / Accepted: 21 January 2013 / Published: 29 January 2013

\begin{abstract}
English wood pastures have become a target for ecological restoration, including the restoration of pollarded trees and grazing animals, although pigs have not been frequently incorporated into wood pasture restoration schemes. Because wood pastures are cultural landscapes, created through the interaction of natural processes and human practices, a historical perspective on wood pasture management practices has the potential to provide insights for modern restoration projects. Using a wide range of both written and artistic sources form the Middle Ages, this article argues that pigs were fed in wood pastures both during the mast season when acorns were available and at other times as grazing fields. Pollarded pedunculate oak (Quercus robur) likely dominated these sustainable cultural landscapes during the medieval period.
\end{abstract}

Keywords: swine; oaks; woodlands; restoration; Middle Ages; history

\section{Introduction}

Wood pastures have long been identified as particularly important for habitat conservation [1-4]. Scattered trees, such as those in the dehesa pasture areas of Spain, have been identified as keystone structures at both local and landscape ecological scales [5]. The large old trees on a wood pasture serve as biodiversity hotspots because they provide habitat for bat and bird species, lichens, fungi, and invertebrates and the surrounding pasture and open woodland serves as the home for flowering plants, rare butterflies and moths, as well as birds [6].

Wood pastures are cultural landscapes, created through the interaction of natural processes and human practices [3,7]. Wood pastures exist where a relatively high density of grazing domestic livestock or wild animals keep the woodland open with gaps between trees and little or no 
understory [3]. Continual animal browsing/rooting and human weeding will kill back any newly sprouted trees and bushes, keeping back re-afforestation and making room for nutrition-rich grasses on the oak savannas. Trees on pasture-woodland are often pollards, which are trees cut at a cyclical interval (often 10+ years) 2-3 m above the ground in order to keep the new shoots out of the range of browsing animals. Pollarding can significantly prolong the life of oak (Quercus robur and Q. petraea) and beech (Fagus sylvatica) trees — ancient pollards over 400 years are still found in England [2].

English wood pastures have become a target for ecological restoration (e.g., [6,8-10]), including the restoration of pollarded trees $[11,12]$. Guidance about woodlands and wood pasture restoration in the UK has advocated livestock grazing in some cases to improve structural and species diversity $[6,10,12]$. Although pigs have been mentioned as a potential grazer [13], the implementation of restoration through grazing in the UK has focused on cattle, ponies, and sheep, with only one project listed in the Grazing Animals Project incorporating pigs as a major component [14]. In the restoration of pollarded tree pastures in Epping Forest, only the reintroduction of cattle grazing was promoted [15]. Pigs might, however, prove useful in wood pasture restoration and maintenance. For example, Berkshire pigs have been used to clear weedy species in Burnham Beeches, Buckinghamshire [9]. Sandom et al. found that wild boar could be useful for woodland management in the Scottish Highlands because of their rooting behavior, which acts as a disturbance and provides patches for seedling germination [16]. Domestic pigs likewise increase grassland biodiversity with their rooting, although certain vegetative species can be lost through selective feeding [17].

Because wood pastures are a result of hundreds of years of practices, we need to understand the practices that created the landscapes in order to either restore or conserve them. A historical approach to landscape management in England might thus prove useful for thinking about how these ecosystems can be restored and maintained [18]. There can be rapid loss of cultural knowledge about woodland management, as Rotherham noted in a case study from Sheffield, England [19]. Such is the case with both pollarding and pig management in woodlands: pollarding suffered a precipitous decline after the eighteenth century in Britain so that by the 1950s, it "had become a moribund and almost forgotten practice" [20], and pig management in outdoor systems lost favor in the eighteenth century as well [21]. A historical investigation of the use of pigs in wood pasture can bring to light some of the forgotten practices of the past.

In this article, I examine the medieval evidence for how pig husbandry functioned in wood pasture in England. By combining the insights from a wide array of medieval textual and artistic sources - mostly from England but some Continental evidence is added for support - I piece together a snapshot of the practices involving pigs and pollards. There has been some disagreement about the widespread feeding of pigs in English medieval woodland. Hooke has argued that the main usage of the Weald in southeastern England during the Anglo-Saxon period was wood pasture, most often for swine [22], whereas Rackham has categorized swine pasture as "a famous, though not very important, use of wood-pasture" [23]. In Rackham's classic Ancient Woodland, he does not even mention pigs in his description of wood pasture products [24]. Considering that the dehesa wood pasture system which stresses pig husbandry was in its current form during the Middle Ages [25], a similar wood pasture system might have been present in England during the same era. Thus a reassessment of medieval agricultural practices is in order since it could have implications for wood pasture restoration practice in the 21 st century. 


\section{Results and Discussion}

\subsection{Medieval Pig Feeding on Acorns and Beechnuts}

Pig husbandry has a long history in Europe, where swine have served in both nutritional and religious roles [26]. Pigs have several benefits as livestock: they are particularly flexible in their diets, allowing them to be reared on poorer land than other livestock; and pig meat is well suited for long-term preservation as bacon and ham and an excellent source of fat [27].

Archeological evidence indicates that medieval pigs were generally slaughtered by their second birthday, since by that time they had gained sufficient weight [26]. An important aspect of the weight-gain process was fattening just before slaughter. The fruit of oak trees (acorns) and beechnuts served as a valuable high caloric food source in the fall months, generally late September through December. According to studies of modern Spanish autumn wood pasture feeding, pigs split their effort between eating grass and acorns equally, which provides a balanced fattening diet since the acorn kernel has a low concentration of crude protein but a very high content of crude fat whereas grass is exactly the opposite [28].

In the Middle Ages, this feeding was institutionalized in the practice of pannage, the feeding pigs on acorn or beech mast in the autumn in exchange for a fee, often as an in-kind payment [24,29]. By feeding on the crop of oak acorns or, in some areas beechnuts, the young pigs would be ready for slaughter in December. Because pigs quickly loose weight if food sources are depleted, owners would not want to keep them over the lean winter months unless they were breeding stock or still too small to be worth killing that year. The cycle of swine fattening on acorns followed by slaughter was so important within the medieval agricultural cycle that it became the standard calendar depiction for either October/November or November/December [30,31].

Numerous medieval artistic depictions provide insights into the practices that facilitated pig feeding. More than being simple tropes copied from one artist to another, these images show familiarity with swine management practices - something which almost everyone would have some knowledge of considering the pervasive medieval swine ownership patterns [26] — making the artistic sources useful for understanding historical agricultural practice [32].

Because medieval swineherds relied on acorns to fatten their herds before the onset of winter, they beat the nuts out of the trees with the help of sticks, shook the trees, or climbed up into them to knock down the precious fodder. In the hundreds of images that I have seen, the swineherd is always shown carrying a stick, other than in one case when the swineherd appears to be receiving money for his services [33]. The stick is used for three purposes: as an element for the herder to rest on; as a device to urge the pig to go in a desired direction; and for knocking down acorns/beechnuts. The third of these is by far the most common (Figure 1). The 13th century scholar Bartholomaeus Anglicus commented on this imagery choice saying that because November is the month for fattening swine, it is illustrated with a rustic beating the oak [34]. Ethnographic evidence from 20th century Spain indicates that modern swineherds still beat the oaks, using a long pole to which a smaller stick was attached via a rope to knock down acorns from cork trees [35]. 
Figure 1. Detail of a miniature from the Queeen Mary Psalter, a mansucript made in London or East Anglia, England, between 1310 and 1320, showing swineherds beating down acorns for their pigs [36].

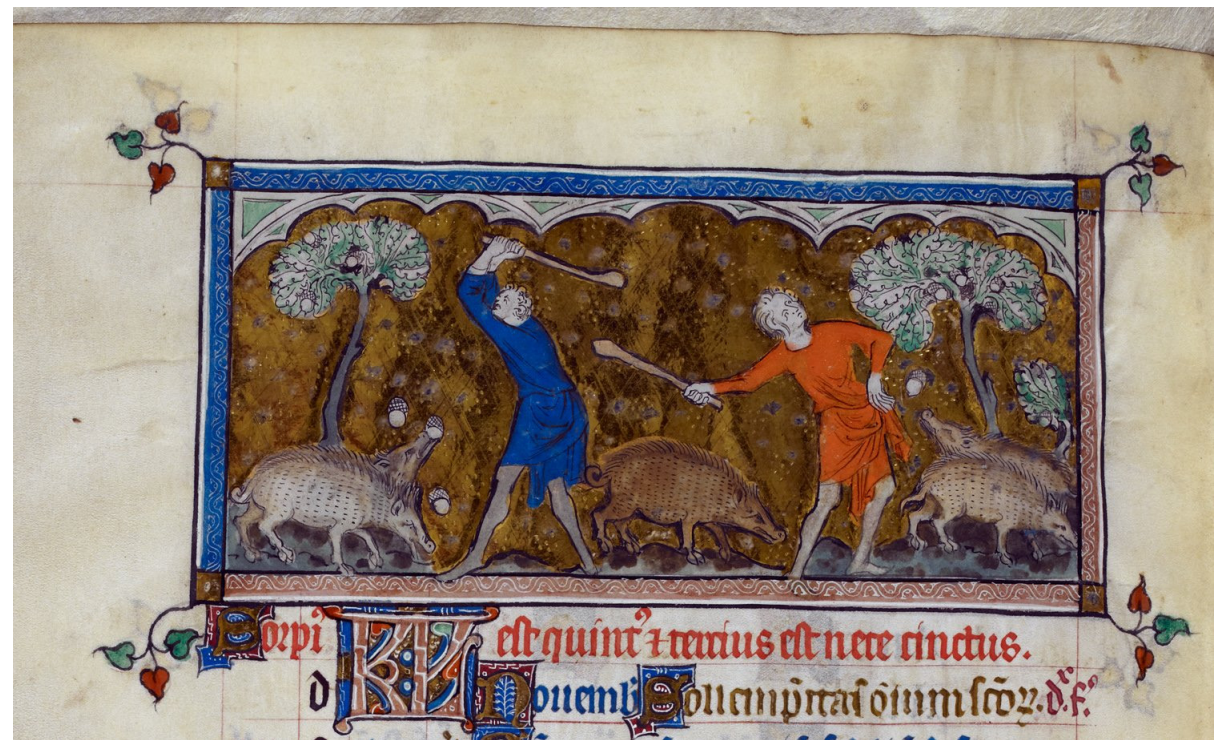

Even with the stick, some acorns high in the tree may have been difficult to knock down, prompting the swineherd to climb the tree. We have several medieval illustrations depicting this activity (Figure 2). The Luttrell Psalter, an early 14th century English manuscript, shows a man sitting up on one of the highest branches using his stick to knock down the top-most acorns for the two hungry pigs below [37]. It has even been argued that the practice of climbing trees to knock down acorns was so common that the Old English poem Christ by Cynewulf refers to it [38].

Figure 2. Detail of the November calendar page from a manuscript made in Metz, France, in 1302 or 1303 showing a swineherd climbing a tree to knock down acorns [39].

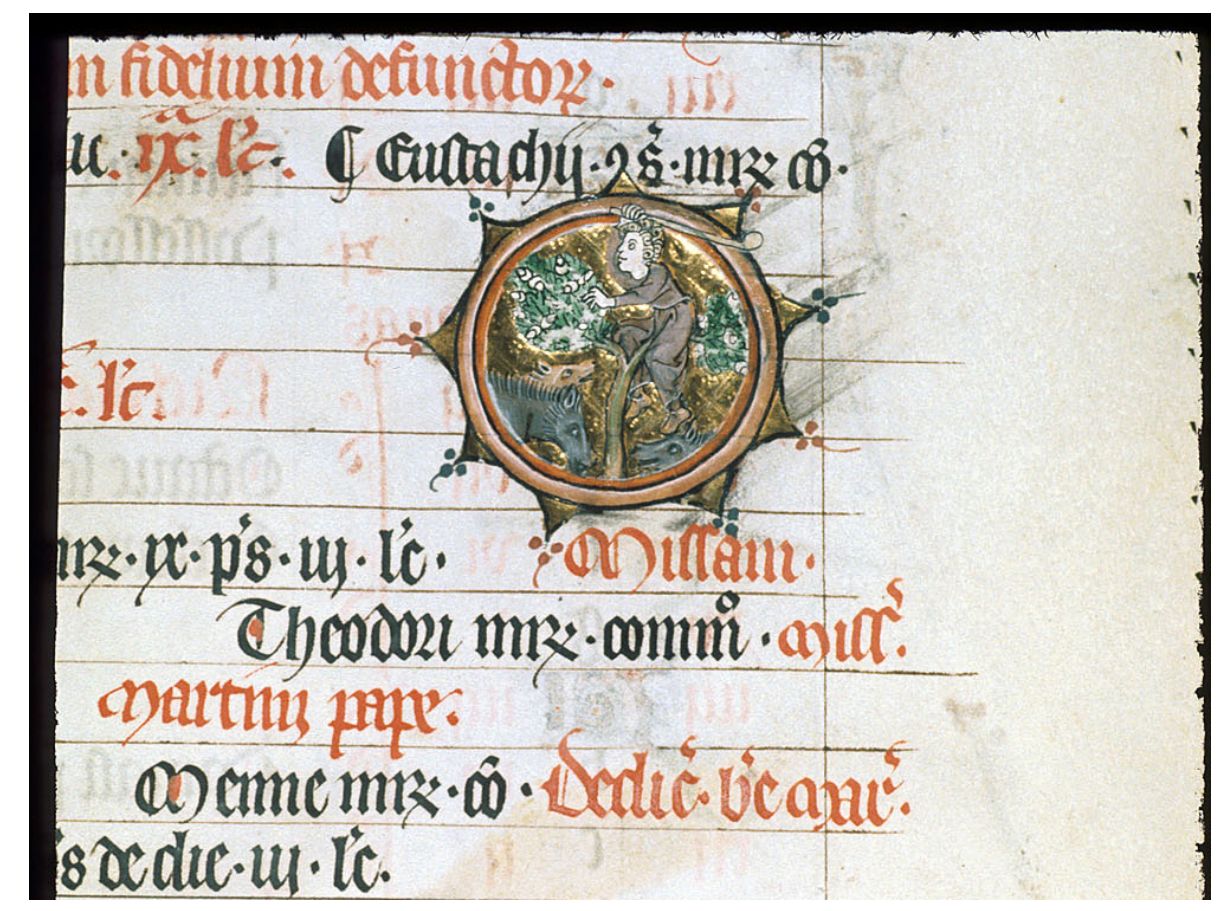


It is possible that after acorns or beechnuts were knocked off the tree, some of them were collected for later use as fodder rather than being consumed on the spot. Some medieval images show the collection of nuts in baskets (Figure 3). Acorn collection is also recorded in a Roman treatise, Opus agriculturae: "At this time, pick the acorn crop and keep it: it is easy work for women and children" [40], advice which was later repeated in the Middle Ages by Vincent of Beauvais [41]. In his sixteenth century book on husbandry, the Englishman Thomas Tusser included a verse about this as well:

To gather some mast, it shall stand thee upon,

With servant and children, ere mast be all gone:

Some left among bushes shall pleasure thy swine;

For fear of a mischief, keep acorns fro kine [42].

If the trees had a particularly productive year or the herd was smaller than usual, collected acorns and beechnuts could be stored and fed to the pigs later.

Figure 3. November calendar page from a manuscript made in Bruges, Netherlands, between 1496 and 1506, showing the feeding of swine in an open wood pasture and the collection of extra nuts in a sack [43].

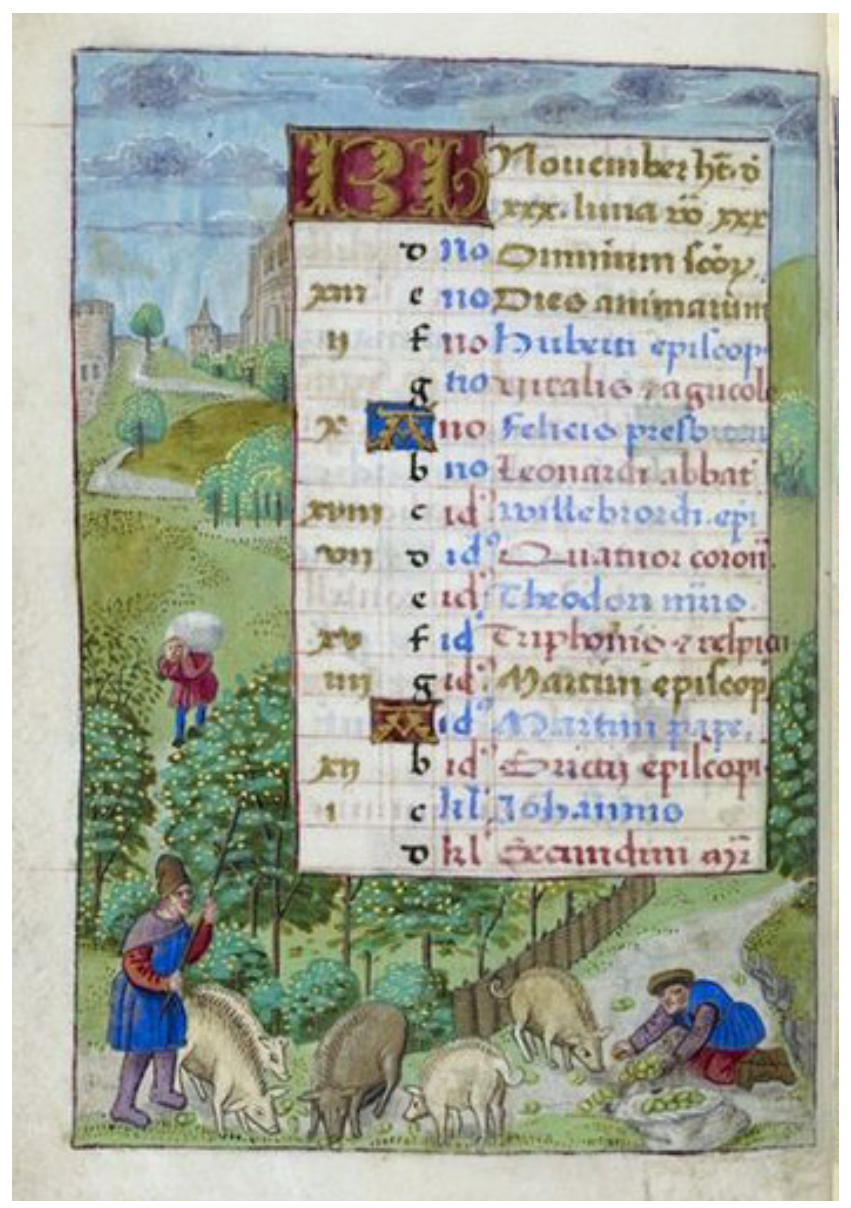

Most of the images in medieval manuscripts are clearly oak trees with oak leaves and acorns (Figures 1 and 2). However, there are drawings that might be representing beech (e.g., Figure 3 and [44]). In a text written in the late 1700s, the author says hogs were taken "especially among the 
oaks and beeches" of a wood pasture and open forest area of the New Forest called Boldrewood during the pannage season [45], indicating that the nuts of both tree species were used as pig fodder at the time. The relative importance of the two different trees is not certain for medieval wood pasture, but according to pollen records, oak was much more dominant until the last 200-300 years in the New Forest $[46,47]$.

While the artistic and literary evidence indicates that pigs were fed on oak acorns, it is not forthcoming about the size of the pig herds. For that, we have to turn to medieval financial records. The most well known source attesting to pannage numbers are Domesday Book and Little Domesday Book, a series of documents that summarized data gathered as part of an audit of the royal fisc in the 1080s [48]. In the inquest documents, the scribes often recorded the size of a woodland based on how many swine could be fed in it (silva $n$ porcis), which made sense as part of a financial audit because the king as a landholder could assess pannage fees from swine owners. These records can be useful for indicating the relative importance of swine versus other livestock: for example, in the Norfolk records, sheep are by far the dominant stock with over 46,000 recorded, but pigs at a little over 8000 are likewise much more prevalent than cows (23) or horses (106 domesticated and 139 wild) [49]. The herd sizes recorded in Domesday could be quite large, as in Luton, Bedfordshire, which is listed as holding two woods that could feed 2050 swine total [50]. A few of the detailed entries for holdings in the New Forest listed multiple moderately-sized herds, including Eling which had "wood yielding 280 swine for the pannage," Holdenhurst with wood yielding 129 swine, and Ringwood with wood yielding 189 swine [51]. An extensive study of English manorial agriculture from 1250 to 1450 showed that swine were most important as an agricultural product in northern England and the northwest midlands and in the pastoral systems of the Weald in Kent and Sussex [52]. Although medieval herd sizes cannot always be correlated to woodland quantity available at a specific manor [53], swine herding appears to be generally associated with woodland and wood pasture in medieval England.

Rackham argued that Domesday records could not be recording actual swine numbers feeding in the woods because acorn crops are variable [54]. But this might not be the case. Although recent oak silviculture studies demonstrate that acorn production ranges from very poor, in which a small proportion of the trees have acorns, to very good, in which nearly all trees have a heavy crop [55], the studies show that moderate crop sizes are just as common as extreme years [56]. Excellent crop years (called "mast" years), for the pedunculate oak occur every two to six years [57]. Thus acorns were probably available almost every year in the medieval English oak woods even though the amount was highly variable. While the numbers of pigs listed in Domesday might not be accurate for each and every year, they reflect the approximate size of the herds that could be fattened in the area in spite of acorn variability.

\subsection{Medieval Pig Grazing in Pasture}

Although pigs were deliberated fattened on acorns and beechnuts, tree fruits could not be their only source of nutrition because of the limited seasonality of the crop. For the rest of year, swine could graze on grass, tubers, and roots; eat stubble of harvested grain crops such as barley and wheat; and consume leftovers such as brewery dregs or household food wastes [26]. Feeding swine grain fit for 
human consumption was not a preferred strategy because of the increased cost, according to a 15 th century agricultural tract [58]. According to a 14th century husbandry handbook titled Seneschaucy, owners were encouraged to provide food directly to their herd only during severe frost; the rest of the time, the pigs should find their own food in forest, wood pasture, marsh, or untilled fields [59]. However, manorial records from the estates owned by Peterborough Abbey in eastern England indicate that pigs were regularly fed on grain and legumes there, probably because most of the nearby land was in crop production [53].

Grasslands for swine pasture must have been abundant in most places and the quality of pasturage was likely key to swine rearing in the Middle Ages [60]. Parsons noted that pasture quality and quantity was just as important as the size of the acorn crop in valuation of pig pastures in southwestern Spain, where woodland-fed swine were still common in the early 1960s [35]. Even when acorns are present, pigs consume large quantities of grass, as well as roots and rhizomes of plants such as bracken fern (Pteridium sp) and couch-grass (Agropyrum repens) [28,54]. Palladius, a Roman writer from the fourth century who was translated into Middle English verse, noted that pigs did well in oak woodlands because of the acorns as well as herbage in the grasslands underneath [61]. Rooting was likewise acknowledged in medieval times as a critical feeding strategy [62]. Tusser recorded a verse highlighting the role of both acorns and braken fern rhizomes ("brake-rootes") as swine food:

Get pole, boy mine!

Beate hawes to swine.

Drive hog to the wood,

Brake-rootes be good [42].

In the foundation charter of Lessay abbey in Normandy, which at that time was part of the Anglo-Norman kingdom, the monks were permitted "to have pasture for all their animals and for all their pigs, as well as pasture for the animals of the servants who take care of the monks' herds; if the pigs are sent to graze inside the park, the monks shall have the right freely to graze one hundred pigs from Martinmas until Lent" [63]. In this example, the grazing was over the winter and spring after the acorn-feeding period, showing that grazing in wood pastures was integral to medieval pig husbandry.

\subsection{Combining Grazing and Acorn Feeding in Wood Pasture}

Wood pasture with pedunculate oak pollards would have been an appropriate agricultural landscape in the Middle Ages to maximize the combination of acorn and grass production. This choice is supported by two factors.

First, acorn production may be increased by pruning and cultivating trees as pollards in wood pasture rather than high forest. Although pollards in northern Europe might be thought of as fodder producers through branch and leaf harvesting or wood producers (e.g., [64]), the pollarded oak stands in Spain are currently managed for their acorn production [35,65]. In the dehesa system, the oaks are pruned to encourage outward growth rather than upward growth so that the light is increased and the acorn-bearing branches are at a more convenient height, creating an open landscape with trees that have open and productive canopies [35]. Although there are ecological differences between the systems - the dehesa is dominated by holm oak (Q. ilex) and cork oak (Q. suber) instead of Q. robur 
and $Q$. petraea - the link between medieval tree management techniques and acorn production for swine feeding may have been similar. Acorn production occurs most often on branches exposed to light [55]. Thus, oaks do especially well in open pastures where they are not shaded. Pruning or pollarding the tree increases light exposure of the branches, which is believed to lead to better acorn crops on the dehesa [35,65], although one more recent study has questioned increased productivity [66]. In any case, the result of the management is an open landscape with widely spaced open canopy trees.

When medieval illustrations show more than one tree in pannage scenes, they most often depict pigs feeding among widely spaced trees rather than dense forest [67]. Keeping in mind that artistic images reflect stylistic choices as well as reality, some of the images of pannage indicate managed trees with the lower branches of the trees pruned away [68]. An illustration in a 12th century manuscript shows a swineherd knocking down acorns from a more clearly pollarded tree (Figure 4).

Figure 4. Detail of a miniature in a manuscript made in England, c. 1170, showing acorns being knocked down from a pollarded tree [69].

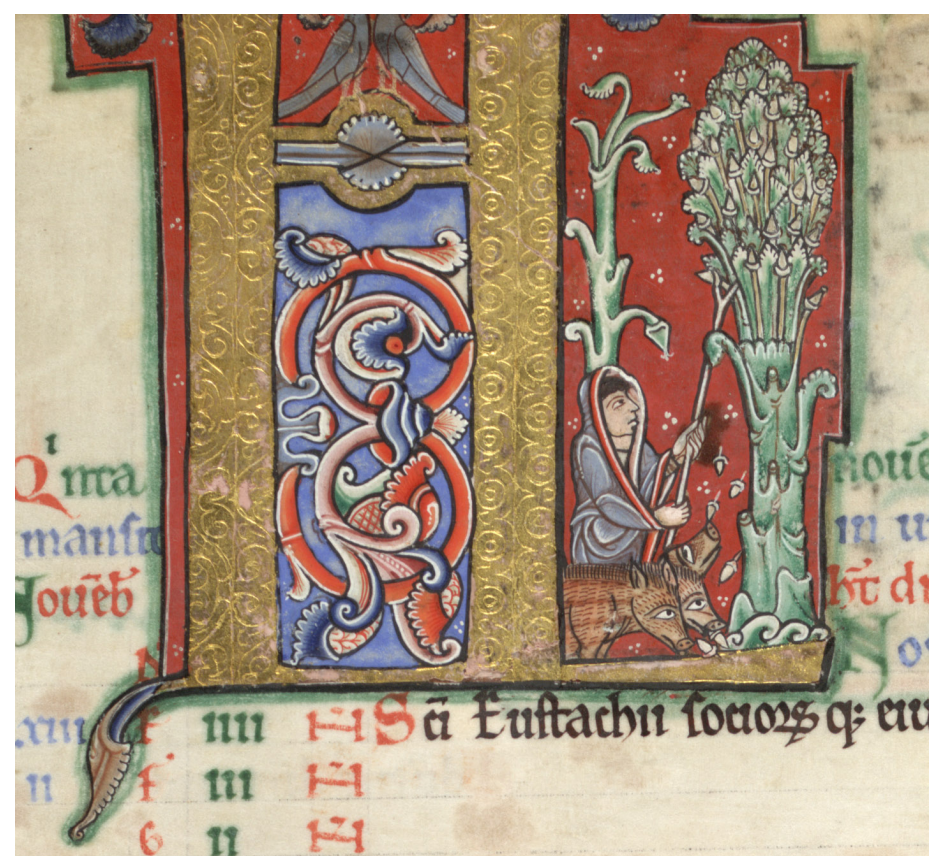

Second, of the two primary types of oaks in Britain, pedunculate oak (Q. robur) and sessile oak ( $Q$. petraea), the pedunculate has a more suitable acorn configuration. Pedunculate oaks have larger acorns, heavier acorn crops, and bear crops at a younger age than sessile oaks, and the larger pedunculate acorns are also easier to store over the winter [57]. Most importantly, in pedunculate oak, the acorn grows on a stem that extends from the main branch (called the pedunculate), making it easier to knock off. Because of this difference, swineherds would have preferred to feed their swine in pedunculate oak woodlands, a fact shown in the medieval illustrations. Although many illustrations do not show the acorns on the trees, when they are present, they are unmistakably on pedunculates, such as in the Luttrell Psalter [37] and the Hours of Jeanne d'Evreux [70].

Although we do not know the extent of human selection for pedunculate oaks over sessile, we can assume that the pedunculate's favorable characteristics prompted people in the Middle Ages to try to 
maximize their presence [57]. This could have taken place through selective planting or by leaving only good producing trees in wood pastures. Rackham noted that pedunculate oak was much more common than sessile oak in remanent medieval wood pastures like Epping and Windsor Forests even though the opposite would be expected from the soil characteristics of the site [24]. This could be because of medieval selection pressure on seedlings. Certainly by the 16th and 17th centuries, evidence exists that pedunculate oaks were preferred for planting in England's oak plantations [57]. It is therefore likely that medieval people also made sure that most of the oaks in wood pastures were pedunculate oaks in order to feed their swine most effectively.

\section{Conclusions}

Although cattle, sheep, and horses are often mentioned in conjunction with wood pasture restoration projects in the UK, this medieval evidence indicates that pigs may have been just as important a driver in the creation and maintenance of medieval wood pasture. The medieval swine husbandry regime depended on oak acorns and grass pasture with some rhizomatic plants, as the evidence above indicates. Pigs fed in wood pasture not only for acorns during the pannage season, but also as regular grazing grounds. High forest, in which the trees grow densely and shade the forest floor, is not conducive to either growing edible grasses or acorn production. Wood pasture, on the other hand, is a long-practiced livestock husbandry system in Europe, which opens the field up to sunlight, benefiting both grasses and light-loving trees [23]. Wood pasture rather than closed forest would have thus dominated medieval swine management.

Swine have quite different effects on vegetation than cattle and ponies. Cattle and ponies are bulk grazers with cattle often tearing off leaves, which can damage young trees, and ponies biting grasses close to the ground; pigs, on the other hand, are omnivorous foragers that obtain much of their food by rooting as well as grazing on herbs [13]. From a restoration perspective, the grazing and rooting of pigs offers the potential for pigs to restore pasture through control of weedy ground cover plants like bracken [71] and to create available seed beds by loosening the soil [16]. Although toxic effects from bracken at high consumption rates have been seen in laboratory studies, e.g., [72], swine appear to be unaffected by bracken consumption as part of a more balanced diet [42,71,73]. Pigs also help maintain the open character of wood pasture through killing saplings that would otherwise colonize the area. These traits, while potentially useful for wood pasture restoration, are disruptive in tropical forest ecosystems, where introduced feral pigs pose threats to native vegetation. In these cases, forest restoration is often predicated on pig removal [74].

Since pedunculate oak trees rather than either sessile oak or beech appears to have been the tree of choice for medieval wood pastures, tree restoration, whether planting saplings or resuming pollarding, should focus on pedunculate oaks. Pollarding schemes on very long cycles, i.e., over 10 years, would appear to be most appropriate.

The synergies between pigs and wood pasture in the Middle Ages is relevant for ongoing restoration and management efforts of Britain's ancient wood pastures. If we want wood pasture ecosystems to be sustainable over the long-term, serious consideration should be given to reintroducing the combination of pig grazing and pollarding. From an ongoing management 
perspective, herding pigs helped create the legacy of the open wood-pasture landscape in the UK and might conserve those types of landscapes in the future.

\section{Acknowledgments}

An earlier version of this article was presented as a keynote lecture at the Texas Medieval Association 2012 Annual Meeting. Thanks to Sally Vaughn for inviting me to speak at that occasion and to the conference attendees for their thoughtful suggestions and comments. Financial support was provided by the project "Ecosystem restoration in policy and practice: restore, develop, adapt" (RESTORE), funded by the Swedish research council FORMAS.

\section{Conflict of Interest}

The author declares no conflict of interest.

\section{References and Notes}

1. Peterken, G.F. Habitat conservation priorities in British and European woodlands. Biol. Conserv. 1977, 11, 223-236.

2. Rackham, O. Trees and Woodland in the British Landscapes; Dent: London, UK, 1990.

3. Kirby, K.J.; Thomas, R.C.; Key, R.S.; McLean, I.F.G.; Hodgetts, N. Pasture-woodland and its conservation in Britain. Biol. J. Linn. Soc. 1995, 56, 135-153.

4. Bergmeier, E.; Petermann, J.; Schröder, E. Geobotanical survey of wood-pasture habitats in Europe: Diversity, threats and conservation. Biodivers. Conserv. 2010, 19, 2995-3014.

5. Manning, A.D.; Fischer, J.; Lindenmayer, D.B. Scattered trees are keystone structures-Implications for conservation. Biol. Conserv. 2006, 132, 311-321.

6. Forestry Commission Scotland. Management of Ancient Wood Pasture; Forestry Commission Scotland: Edinburgh, UK, 2009.

7. Quelch, P.R. Structure and utilization of the early oakwoods. Biol. J. Scotland 2005, 57, 99-105.

8. Butler, J. Examples of the maintenance and restoration of wood pasture sites in the UK and the potential for creation. In Pasture Landscape and Nature Conservation; Redecker, B., Finck, P., Härdtle, W., Rieken, U., Schröder, E., Eds.; Springer: Berlin, Germany, 2002; pp. 266-272.

9. Spencer, J. Managing wood pasture landscapes in England; the New forest and other more recent examples. In Pasture Landscape and Nature Conservation; Redecker, B., Finck, P., Härdtle, W., Rieken, U., Schröder, E., Eds.; Springer: Berlin, Germany, 2002; pp. 123-136.

10. Thompson, R.N.; Humphrey, J.W.; Harmer, R.; Ferris, R. Restoration of Native Woodland on Ancient Woodland Sites; Forestry Commission: Edinburgh, UK, 2003.

11. Mitchell, P.L. Repollarding large neglected pollards: a review of current practice and results. Arboricultural J. 1989, 13, 125-142.

12. Alexander, K.N.A. Historic parks and pasture-woodlands: The national trust resource and its conservation. Biol. J. Linn. Soc. 1995, 56, 155-175.

13. Mayle, B. Domestic Stock Grazing to Enhance Woodland Biodiversity; Information Note; Forestry Commission: Edinburgh, UK, 1999. 
14. Grazing Animals Project. Available online: http://www.grazinganimalsproject.org.uk (accessed on 8 January 2013).

15. Dagley, J. Pollarding in Epping Forest. In Proceedings of the ler Colloque Européen sur les Troges, Vendôme, France, 26-28 October 2006. Available online: http://www.maisonbotanique. com/dyn/15acte_6_dagley.pdf (accessed on 8 January 2013).

16. Sandom, C.J.; Hughes, J.; Macdonald, D.W. Rooting for rewilding: Quantifying wild boar's Sus scrofa rooting rate in the Scottish Highlands. Restor. Ecol. 2012, doi: 10.1111/j.1526100X.2012.00904.x.

17. Beinlich, B.; Hill, B.; Köstermeyer, H.; Beck, L.; van Rhemen, K. Schweinefreilandhaltung in der Landschaftspflege - ein Überblick zum aktuellen Kenntnisstand. Egge-Weser 2001, 14, 15-30.

18. Rotherham, I.D. Implications of landscape history and cultural severance for restoration in England. In Human Dimensions of Ecological Restoration: Integrating Science, Nature, and Culture; Egan, D., Ed.; Island Press: Washington, DC, USA, 2011; pp. 277-287.

19. Rotherham, I.D. The implications of perceptions and cultural knowledge management of wooded landscapes: A UK case-study. Forest Ecol. Manag. 2007, 249, 100-115.

20. Petit, S.; Watkins, C. Pollarding trees: Changing attitudes to a traditional land management practice in Britain 1600-1900. Rural Hist. 2003, 14, 157-176.

21. Thorton, K. Outdoor Pig Production; Farming Press: Ipswich, UK, 1990.

22. Hooke, D. Trees in Anglo-Saxon England; Boydell Press: Woodbridge, UK, 2010.

23. Rackham, O. The Illustrated History of the Countryside; Weidenfeld \& Nicolson: London, UK, 2003.

24. Rackham, O. Ancient Woodland: Its History, Vegetation and Uses in England; Edward Arnold: London, UK, 1980.

25. Clement, V. Spanish wood pasture: Origin and durability of an historical wooded landscape in Mediterranean Europe. Environ. Hist. 2008, 14, 67-87.

26. Albarella, U. Pig husbandry and pork consumption in medieval England. In Food in Medieval England: Diet and Nutrition; Woolgar, C.M., Serjeantson, D., Waldron, T., Eds.; Oxford University Press: Oxford, UK, 2006; pp. 72-87.

27. Ten Cate, C.L. Wan god mast gift: Bilder aus der Geschichte der Schweinezucht im Walde; Centre for Agricultural Publishing and Documentation: Wageningen, the Netherlands, 1972.

28. Rodríguez-Estévez, V.; Garcia, A.; Pena, F.; Gómez, A.G. Foraging of Iberian fattening pigs grazing natural pasture in the dehesa. Livest. Sci. 2009, 120, 135-143.

29. Shaw, E.B. Geography of mast feeding. Econ. Geogr. 1940, 16, 233-249.

30. Henisch, B. The Medieval Calendar Year; Pennsylvania State University Press: University Park, PA, USA, 1999.

31. Hourihane, C. Time in the Medieval World: Occupations of the Months \& Signs of the Zodiac in the Index of Christian Art; Princeton University Press: Princeton, NJ, USA, 2007.

32. Janick, J. Art as a Source of Information on Horticultural Technology. In IHC2006: Global Horticulture: Diversity and Harmony, Acta Horticulturae 759; Janick, J., Ed.; International Society for Horticultural Science: Seoul, South Korea, 2007; pp. 69-88.

33. Pierpont Morgan Library, MS S.97 f.11v, New York, NY, USA.

34. Bartholomeus Anglicus. De Proprietatibus Rerum; Anton Koberger: Nuremberg, Germany, 1483. 
35. Parsons, J.J. The acorn-hog economy of the oak woodlands of southwestern Spain. Geogr. Rev. 1962, 52, 211-235.

36. British Library, Royal 2 B VII, f. 81v. Image in the public domain; digital image courtesy of British Library, London, UK.

37. British Library, Add. MS 42130, f. 59v, London, UK.

38. Meritt, H. Beating the oaks: An interpretation of Christ 678-9. Am. J. Philology 1945, 66, 1-12.

39. British Library, Yates Thompson 8, f. 6. Image in the public domain. Digital image courtesy of British Library, London, UK.

40. Schmitt, J.C., Ed. Opus Agriculturae; Teubner: Leipzig, Germany, 1898.

41. Vincent of Beauvais. Speculi Maioris; Dominicum Nicolinum: Venice, Italy, 1541; Book 6, Volume 2, Chapter 148.

42. Tusser, T. Five Hundred Points of Good Husbandry; Mavor, W., Ed.; Lackington, Allen, and Co.: London, UK, 1812.

43. British Library, Additional 18852, f. 11v. Image in the public domain; digital image courtesy of British Library, London, UK.

44. Fitzwilliam Museum, Ms 1058-1975, f. 11, Cambridge, UK.

45. Gilpin, W. Remarks on Forest Scenery and Other Woodland Views; Fraser \& Co.: Edinburgh, UK, 1834; Volume 2, p. 165.

46. Mountford, E.P.; Peterken, G.F.; Edwards, P.J.; Manners, J.G. Long-term change in growth, mortality and regeneration of trees in Denny Wood, an old-growth wood-pasture in the New Forest (UK). Perspect. Plant Ecol. Evol. Systemat. 1999, 2, 223-272.

47. Grant, M.J.; Edwards, M.E. Conserving idealized landscapes: past history, public perception and future management in the New Forest (UK). Veg. Hist. Archaeobot. 2008, 17, 551-562.

48. Roffe, D. Domesday: The Inquest and the Book; Oxford University Press: Oxford, UK, 2000.

49. Darby, H.C. The Domesday Geography of Eastern England, 3rd ed.; Cambridge University Press: Cambridge, UK, 1971; p. 142.

50. Darby, H.C. The Domesday Geography of South-Eastern England; Cambridge University Press: Cambridge, UK, 1971; p. 30.

51. Darby, H.C. The Domesday Geography of South-Eastern England; Cambridge University Press: Cambridge, UK, 1971; p. 336.

52. Campbell, B.M.S. English Seigniorial Agriculture 1250-1450; Cambridge University Press: Cambridge, UK, 2000; p. 168.

53. Biddick, K. Pig Husbandry on the Peterborough Abbey State from the Twelfth to the Fourteenth Century AD. In Animals and Archeology, Husbandry in Europe; Grigson, C., Clutton-Brock, J., Eds.; BAR: Oxford, UK, 1984; Volume 4, pp. 161-177.

54. Rackham, O. Trees and Woodland in the British Landscapes; Dent: London, UK, 1990; p. 48.

55. Johnson, P.S.; Shiffley, S.R.; Rogers, R. Ecology and Silviculture of Oaks; CABI Publishing: Wallingford, UK, 2002.

56. Koenig, W.B.; Knops, J.M.H. The behavioral ecology of masting in oaks. In Oak Forest Ecosystems; McShea, W.J., Healy, W.M., Eds.; Johns Hopkins University Press: Baltimore, MD, USA, 2002; pp. 129-148.

57. Harris, E.; Harris, J.; James, N.D.G. Oak: A British History; Windgate Press: Oxford, UK, 2003. 
58. Anonymous. Seneschaucy. In Walter of Henley's Husbandry; Lamond, E., Ed.; Longmans, Green and Co.: London, UK, 1890; p. 29.

59. Oschinsky, D. Walter of Henley and Other Treatises on Estate Management and Accounting; Clarendon Press: Oxford, UK, 1971.

60. Trow-Smith, R. A History of British Livestock Husbandry to 1700; Routledge and Kegan Paul: London, UK, 1957.

61. Lodge, B. Palladius, on Husbondrie; Early English Text Society: London, UK, 1879.

62. Lamond, E. Walter of Henley's Husbandry; Longmans, Green, and Co.: London, UK, 1890.

63. Bates, D. Regesta Regum Anglo-Normannorum: The Acta of William I (1066-1087); Oxford University Press: Oxford, UK, 1998; no. 175.

64. Read, H.J. Pollards and pollarding in Europe (edited version of Read, 2007). J. Practical Ecol. Conserv. 2009, 8, 86-88.

65. Joffre, R.; Vacher, J.; de los Llanos, C.; Long, G. The dehesa: An agrosilvopastoral system of the Mediterranean region with special reference to the Sierra Morena area of Spain. Agroforest. Syst. 1988, 6, 71-96.

66. Cañellas, I.; Roig, S.; Poblaciones, M.J.; Gea-Izquierdo, G.; Olea, L. An approach to acorn production in Iberian dehesas. Agroforest. Syst. 2007, 70, 3-9.

67. Some examples include British Library Royal 2 B VII, f. 81v, London, UK; Bibliotèque nationale de France Latin 18014, f. 5v, Paris, France; Bodleian Library MS. Buchanan e. 3, f. 7r, Oxford, UK; and Pierpont Morgan Library MS M.64, f. 11r, New York, USA.

68. Some examples include British Library Royal 2 B II, f. 6, London, UK; British Library Royal 2 B III, f. 7, London, UK; and Koninklijke Bibliotheek 76 F 13, f. 11v, Hague, Netherlands.

69. Glasgow University Library MS Hunter 229, f. 6. Image in the public domain; digital image courtesy of University of Glasgow, Glasgow, UK.

70. Metropolitan Museum of Art, The Cloisters Collection, 1954, f. 11v, New York, USA.

71. Randall, C. Pigs in Bracken, 2006. Available online: http://www.grazinganimalsproject.org.uk /focus_on_pigs.html?publication=1;123 (accessed on 8 January 2013).

72. Evans, W.C.; Widdop, B.; Harding, J.D. Experimental poisoning by bracken rhizomes in pigs. Vet. Rec. 1972, 90, 471-475.

73. Thomson, C.; Challies, C.N. Diet of feral pigs in the Podocarp-Tawa forests of the Urewera ranges. New Zeal. J. Ecol. 1988, 11, 73-78.

74. Cole, R.J.; Creighton, C.M.; Koontz, M.J.; Loh, R.K. Vegetation recovery 16 years after feral pig removal from a wet Hawaiian forest. Biotropica 2012, 44, 463-471.

(C) 2012 by the authors; licensee MDPI, Basel, Switzerland. This article is an open access article distributed under the terms and conditions of the Creative Commons Attribution license (http://creativecommons.org/licenses/by/3.0/). 